\title{
A Hong Kong University First \\ Establishing service-learning as an academic credit-bearing subject
}

\author{
Carol Ma Hok Ka \\ Alfred Chan Cheung Ming
}

Lingnan University

Gateways: International Journal of Community Research and Engagement Vol 6 (2013): 178-98 (C) UTSePress and the authors

ISSN 1836-3393
The benefits of service-learning (S-L) for the intellectual and personal development of students, as well as its value as a platform for campus-community partnerships, have been much discussed in the past few decades (Astin et al. 2000, 2006; Xin \& Ma 2010). The term 'service-learning' was coined in 1967 in the US and its growth on college campuses there has since been witnessed. The concept and practice were further developed in Asia following an international conference on S-L in Chiang Mai, Thailand, in 2004, organised by the International Partnership for Service-Learning and Leadership (IPSL). Hong Kong and China, for example, later began to adopt the pedagogy in their curricula (Chan \& Ma 2006). Lingnan University (LU), with its liberal arts mission, was the first university in Asia to institutionalise S-L by establishing the Office of Service-Learning (OSL) in 2006. The OSL plays a vital role in collaborating with other academic departments to offer a real-life opportunity for students to apply in the community the knowledge and skills that they have gained from coursework, and to integrate useful knowledge with practice.

Service-learning is defined as:

[a] course-based, credit bearing educational experience in which students (a) participate in an organized service activity that meets identified community needs, and (b) reflect on the service activity in such a way as to gain further understanding of course content, a broader appreciation of the discipline, and an enhanced sense of civic responsibility (Bringle \& Hatcher 1995, p. 112).

It is an innovative pedagogy that connects theory and practice; through performing high-quality community service, students put their academic knowledge into practice. Their studies are in turn reinforced and learning deepened through the process of critical thinking and self-reflection. In other words, S-L allows students to:

1 participate in an organized service activity that meets identified community needs; 
2 reflect on the service activity in such a way as to gain a further understanding of the course contents; and

3 learn to care, serve and be socially-aware and responsible (Bringle \& Hatcher 1995, p. 112).

The S-L program at LU and all related courses and activities are supported by the OSL. The roles of the OSL are to identify the needs of society, conduct training and reflective meetings about the social issues which need to be addressed, and work with staff in partnering departments and service agencies to ensure that the intended learning outcomes are met. It was stipulated in the 2011 University Development Plan that S-L would be a graduation requirement in 2014-15.

Currently S-L at LU comprises three different modes:

- Mode 1. Community-based service-learning activities: students participate in non-credit-bearing S-L activities locally and internationally, for example, a community outreach program in developing Asian countries. A minimum of 30 hours of subjectrelated community services is required.

- Mode 2. Partially Integrated Course Mode: students participate in S-L associated with credit-bearing courses offered by other academic departments (also known as departmental courses). Students undertaking this mode normally use their tutorial hours for service - in practice, a trade-off of two service hours for one tutorial hour (a total of 15 hours); other course requirements such as lecture attendance remain the same. The service element in these courses is closed related to the learning objectives and course content. An example of this is devising business plans for local social enterprises as part of the Strategic Management course offered by the Department of Management. Students are normally placed with an agency where they carry out their services (projects) in groups of four to five for a minimum of 30 hours a term. Projects are graded by course instructors, agency supervisors and OSL coordinators.

-Mode 3. Fully Integrated Course Mode: students participate in credit-bearing S-L courses offered by OSL, 'Community Engagement through Service-Learning' and 'Cross-border Service-Learning Summer Institute'. These courses are also called independent courses. Students in this mode devote their entire contact hours to S-L and they also have to attend lectures and seminars offered by OSL; it is a form of work-based learning.

$S$ - $L$ is currently integrated in the majority of the university disciplines, forming part of the undergraduate program. The following sections will discuss in more depth the history and development of the whole program, how the program actually operates and the lessons learned while institutionalising servicelearning at Lingnan. 


\section{DEVELOPMENT OF SERVICE-LEARNING AT LINGNAN UNIVERSITY}

\section{From Community Service to Service-Learning}

Even before the establishment of OSL in 2006, because of its longstanding motto 'Education for Service', LU emphasised both academic studies and community service. Service among students was mainly promoted by the Student Services Center through different projects conducted in cooperation with non-government organisations (NGOs) and the government. The Asia-Pacific Institute of Ageing Studies further developed this community engagement by launching the Research Internship Program (RIP) and the Lingnan Angels Program (LAP). In the first term of 2004-05, a pilot Service-Learning and Research Scheme (SLRS) was implemented, mainly funded by the Kwan Fong Charitable Foundation. The primary aim of the SLRS was to offer students opportunities for learning through providing voluntary services to the needy, while also providing initial data for academic research. Under the guidance of course instructors and agencies, students developed positive attitudes and skills (for example, communication and problem-solving skills), and applied their classroom knowledge in serving the community.

The proposal to look at the possibility of developing the Lingnan S-L model followed the successful insertion of what was referred to as a 'service practicum' in two Social Sciences courses, namely 'Crime and Delinquency' and 'Health, Illness and Behaviour', back in 2000. In the practicum component, students spent their tutorial hours (around 15 hours in total) on a subject-related group project. In the projects they applied what they had learned in class in addressing a social need (for example, promoting anti-smoking in schools). The practicum was well received by both the students and the partnering agencies (for example, schools and non-profit organisations).

It was following the aforementioned IPSL International Conference in Chiang Mai, Thailand, that LU started to recognise $\mathrm{S}$-L as a structured educational experience. The former associate vice-president of LU, Professor Barton Starr, led the delegation and provided total support for faculty members to develop courses with an S-L element. With his backing, and a modest donation of HK $\$ 500,000$ secured by the former president, Professor Edward Chen, the Service-Learning and Research Scheme was piloted in 2004.

\section{From Non-Credit-Bearing to Credit-Bearing}

The years between 2004 and 2006 were important landmarks for the development of S-L at LU: S-L components were imbedded across the curriculum. The model emphasised both research and evaluation mechanisms. The service-learning and research scheme: The Lingnan model (Chan \& Ma 2006) was published. Following the successful validation of SLRS, the former president obtained a huge donation to establish a university-wide protocol for service- 
Table 1: Number of LU students joining different S-L modes, 2006-12 learning for the next 10 years. Together with encouragement from the service partners in the local community, the Office of Service-Learning (OSL) was established in 2006 , charged with the following mission:

-To promote LU's motto, 'Education for Service'

-To provide reciprocal benefits to the participants and the community

-To produce a positive developmental impact on student learning and growth

- To enhance learning and teaching efficacy through servicelearning.

The OSL further integrated S-L into Lingnan's liberal arts curriculum (Mode 2), being one of the first among academic institutions in Hong Kong to do so. In 2007 it began offering its own courses with three credits (Mode 3). Overall, almost 3000 students have participated in S-L, with on average of about 400 students participating in the program every year.

The following table shows the number of LU students joining the various S-L modes between 2006 and 2012:

\begin{tabular}{|c|c|c|c|c|c|c|}
\hline Modes & 2006-07 & 2007-08 & 2008-09 & 2009-10 & 2010-11 & 2011-12 \\
\hline $\begin{array}{l}\text { Mode } 1 \\
\text { Community- } \\
\text { based }\end{array}$ & $\begin{array}{l}11 \\
(0.48 \%)\end{array}$ & $\begin{array}{l}129 \\
(5.61 \%)\end{array}$ & $\begin{array}{l}75 \\
(3.26 \%)\end{array}$ & $\begin{array}{l}94 \\
(4.09 \%)\end{array}$ & $\begin{array}{l}145 \\
(6.30 \%)\end{array}$ & $\begin{array}{l}84 \\
(3.65 \%)\end{array}$ \\
\hline $\begin{array}{l}\text { Mode } 2 \\
\text { Partially } \\
\text { Integrated Course }\end{array}$ & $\begin{array}{l}273 \\
(11.87 \%)\end{array}$ & $\begin{array}{l}236 \\
(10.26 \%)\end{array}$ & $\begin{array}{l}343 \\
(14.91 \%)\end{array}$ & $\begin{array}{l}298 \\
(12.96 \%)\end{array}$ & $\begin{array}{l}394 \\
(17.13 \%)\end{array}$ & $\begin{array}{l}390 \\
(16.96 \%)\end{array}$ \\
\hline $\begin{array}{l}\text { Mode } 3 \\
\text { Fully Integrated } \\
\text { Course }\end{array}$ & - & $\begin{array}{l}15 \\
(0.65 \%)\end{array}$ & $\begin{array}{l}7 \\
(0.30 \%)\end{array}$ & $\begin{array}{l}17 \\
(0.74 \%)\end{array}$ & $\begin{array}{l}33 \\
(1.43 \%)\end{array}$ & $\begin{array}{l}24 \\
(1.04 \%)\end{array}$ \\
\hline Total & $\begin{array}{l}284 \\
(12.35 \%)\end{array}$ & $\begin{array}{l}380 \\
(16.52 \%)\end{array}$ & $\begin{array}{l}425 \\
(18.48 \%)\end{array}$ & $\begin{array}{l}409 \\
(17.78 \%)\end{array}$ & $\begin{array}{l}572 \\
(24.87 \%)\end{array}$ & $\begin{array}{l}498 \\
(21.65 \%)\end{array}$ \\
\hline
\end{tabular}

Note: \% denotes the number of students joining S-L program modes out of the total number of students at LU.

\section{From Credit-Bearing to Graduation Requirement}

As LU moved toward a four-year educational model in 2012, S-L has gained in prominence in this liberal arts university. Starting from the 2014 intake, all LU students will have to be involved in one S-L activity or take and pass at least one course with an S-L element before their graduation. This is known as the ServiceLearning Requirement (SLR). Since S-L courses and projects are of different types, there are five principles in determining whether students have successfully fulfilled the SLR, namely community engagement, reciprocity, reflection, public dissemination, and time requirement. Students have to fulfil a minimum threshold requirement under each. These principles follow the theoretical underpinnings of S-L closely, and this will be discussed in detail in the next section.

Moreover, with its experience in S-L, OSL of LU now plays a major role in developing S-L networks among higher education 
institutions in Hong Kong and Asia. The Higher Education ServiceLearning Network (HESLN) in Hong Kong and Service-Learning Asia Network (SLAN) were set up in 2009 and 2011 respectively, and LU serves as the secretariat for both.

In retrospect, the development of S-L at LU was aided by timely support from the President's Office as well as community partners. At the same time, it also adopted the right strategies at the right time. The following section details the theoretical framework for conceptualising S-L at LU, as well as designing its actual operation.

\section{THEORETICAL FRAMEWORK FOR CONCEPTUALISING AND} IMPLEMENTING S-L AT LINGNAN UNIVERSITY

Three main strands of theory and philosophy inform the conceptualisation and implementation of S-L, namely wholeperson education, experiential learning, and knowledge transfer. They are interrelated: without any of the strands, it is difficult to achieve knowledge transfer. Experiential learning is one of the best platforms on which whole-person education can be practised, and as students apply what they learn in real-life situations knowledge transfer results.

\section{Whole-Person Education as a Mission}

$\mathrm{LU}$ is devoted to delivering whole-person education that fosters the development of community leadership; this is exemplified in its 'Profile for the Ideal Lingnan Graduate' ('Profile'), specified in the Strategic Plan for 2009-2016. After their undergraduate program, an ideal Lingnan graduate will:

- have strong oral and written language proficiency in both English and Chinese (Putonghua as well as Cantonese), together with excellent communication and interpersonal skills;

- be committed to involvement in and service of the community;

- have an international outlook and be able to understand problems from different cultural perspectives;

- have a secure grounding in his/her chosen academic field and an awareness of possible cross-disciplinary applications;

— possess essential generic research-related skills, including knowledge of IT;

- have strong analytical skills and a capacity for independent critical thinking;

—be imaginative and possess problem solving capabilities;

-be capable of imaginative and sound planning;

-have excellent communication skills, based on tolerance, integrity, civility, and a sense of personal responsibility;

- have both the capacity and desire for life-long learning. 
Table 2: How S-L intended learning outcomes relate to the 'Profile for the Ideal Lingnan Graduate'
Consistent with the Profile, all educational activities should help students enhance the following skills:

-Communication Skills: having the sensitivity and confidence to communicate with others, and understanding the values of group discussion

-Organization Skills: being able to organize events and others, and feeling competent and empowered to lead others when necessary

-Problem-Solving Skills: being able to identify, frame, and resolve problems.

-Subject-Related Knowledge: being able to identify and apply knowledge related to one's academic subject to authentic situations, and seeing the usefulness of that subject

-Research Skills: being able to frame and conduct information gathering, and understand the importance of this process to knowledge acquisition

-Social Competence: having an increased understanding of others and oneself, and being able to connect with others who are different

-Civic Orientation: feeling empathy for others, having personal responsibility for social situations, and planning for future civic action.

These seven skills and competences are known as the Seven Domains, and at LU can be understood as S-L intended learning outcomes, which guide the design of all courses and service projects. The validity and reliability of the tool (a set of pre- and post-course questionnaires) measuring the Seven Domains have been repeatedly validated in Lingnan's course evaluation and research projects (Chan \& Ma 2009). Table 2 illustrates how each skill/competence is related to the Profile descriptors.

\begin{tabular}{ll}
\hline $\begin{array}{l}\text { Profile for the Ideal Lingnan } \\
\text { Graduate descriptors } \\
\text { (profile of a community leader) }\end{array}$ & $\begin{array}{l}\text { Related service- } \\
\text { learning intended } \\
\text { learning outcomes }\end{array}$ \\
\hline $\begin{array}{l}\text { Have strong oral and written language } \\
\text { proficiency in both English and Chinese } \\
\text { (Putonghua as well as Cantonese), together } \\
\text { with excellent communication and } \\
\text { interpersonal skills }\end{array}$ & Communication skills \\
\hline $\begin{array}{l}\text { Be committed to involvement in and service of } \\
\text { the community }\end{array}$ & Civic orientation \\
\hline $\begin{array}{l}\text { Have an international outlook and be able to } \\
\text { understand problems from different cultural } \\
\text { perspectives }\end{array}$ & Problem-solving skills \\
\hline $\begin{array}{l}\text { Have a secure grounding in his/her chosen } \\
\text { academic field and an awareness of possible } \\
\text { cross-disciplinary applications }\end{array}$ & Subject-related knowledge \\
\hline
\end{tabular}




\begin{tabular}{ll}
\hline $\begin{array}{l}\text { Possess essential generic research-related skills, } \\
\text { including knowledge of IT }\end{array}$ & Research skills \\
\hline $\begin{array}{l}\text { Have strong analytical skills and a capacity for } \\
\text { independent critical thinking }\end{array}$ & Research skills \\
\hline $\begin{array}{l}\text { Be imaginative and possess problem solving } \\
\text { capabilities }\end{array}$ & Problem-solving skills \\
\hline $\begin{array}{l}\text { Be capable of imaginative and sound } \\
\text { planning; }\end{array}$ & Organisation skills \\
\hline $\begin{array}{l}\text { Have excellent cooperative skills, based on } \\
\text { tolerance, integrity, civility, and a sense of } \\
\text { personal responsibility }\end{array}$ & Communication skills \\
\hline $\begin{array}{l}\text { Have both the capacity and desire for life-long } \\
\text { learning }\end{array}$ & Organisation skills \\
\hline
\end{tabular}

\section{Experiential Learning as a Vehicle}

With whole-person education as LU's mission, students at LU are trained to acquire the above skills and knowledge. LU believes that $\mathrm{S}-\mathrm{L}$, as the experiential learning vehicle, is one of the best ways to achieve this as students experience real learning by establishing links between the classroom and the community. Early practitioners of S-L indeed made their pedagogical home in the field of experiential learning (Stanton, Giles \& Cruz 1999), in which life experience is infused with the learning environment and content. Kolb and Fry (1975), in their Experiential Learning Model, suggest that learning occurs when one goes through a cycle consisting of concrete experience, observation of and reflection on that experience, formation of abstract concepts based upon the reflection and testing the new concepts, and that learning can begin with any one of them. John Dewey (1938), the most famous proponent of experiential education, believed that for an experience to be educational certain parameters had to be met, the most important being continuity of and interaction with the experience. In other words, the experience should come from and lead to other experiences, motivating the person to learn more, and should also meet the internal needs or goals of the person.

$\mathrm{S}$ - $\mathrm{L}$ is a form of experiential education in which students engage in a cycle of service and reflection. It provides students with experiences through which they can test and apply what they have learned in the classroom. From LU's experience, students not only integrate knowledge into their service experience, they also investigate social issues through different research methods. While processing knowledge about the community issues investigated through continuous guided reflection and observation, civic engagement is increased; in going through the process of knowledge building, knowledge application and knowledge transfer, students have the opportunity to co-create knowledge (See Figure 1). 
Figure 1: Cycle of reflective learning (developed by the authors in 2004 at the IPSL International Conference in Thailand)

Figure 2: Knowledge building, application and transfer through servicelearning

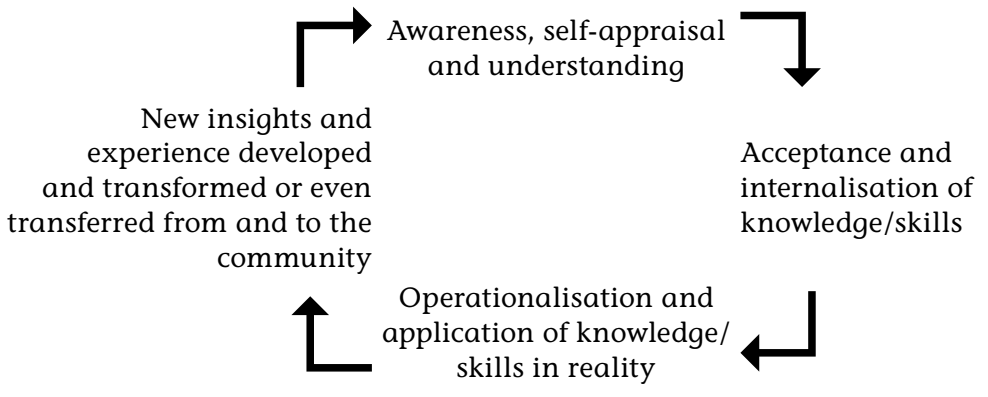

Throughout the process, a cycle of reflective learning is developed. New concepts may also be created as a result of this, upon which another cycle of learning begins. That is to say, learning has to go through several stages: awareness and self-appraisal, internalisation of what has been learned, and understanding of how the knowledge can be operationalised and new skills and knowledge developed and transformed, and even transferred from and to the community (see Figure 2).

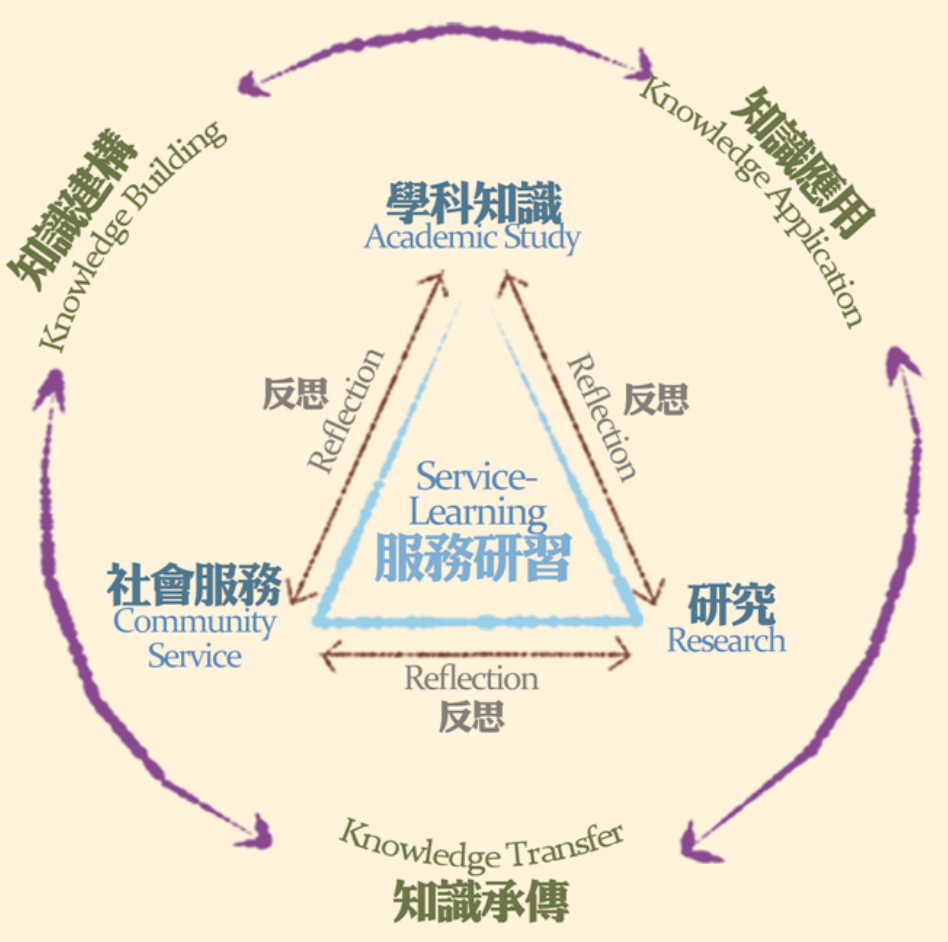

In the S-L program at $\mathrm{LU}$, the service projects are fully integrated into courses (not added to courses) and are designed in such a way that ensures that 'both the service enhances the learning and learning enhances the service' (Furco 1996, p. 5). In other words, the project is intended to provide services to those in need of them as well as to help students better understand the issue they are investigating. This is also precisely why LU very much values the dialogue between academia and the community, which is evident in the establishment of the Community-Faculty Committee and involvement of each stakeholder in the whole course development and implementation process.

\section{Knowledge Transfer as a Process}

With different stakeholders' involvement, Knowledge Transfer (KT) becomes a process, which has emerged from and indeed is a mission of higher education in Hong Kong and China, together 
with teaching and research. The University Grants Committee (UGC) has incorporated KT into its mission statement and institutional mission statement. KT is 'the systems and processes by which knowledge, including technology, know-how, expertise and skills, are transferred between higher education institutions and society, lead[ing] to innovative, profitable or economic or social improvements' (UGC 2012). It is the dissemination of expertise, skills and capabilities from universities as the academic knowledge base to institutions or organisations in need of the knowledge, including non-government organisations and other nonacademic beneficiaries. Knowledge to and from society provides organisations and the targeted population with the means to increase capability and improve conditions (KTO, HKBU 2012).

The ultimate goal of KT is to work with communities, philanthropic networks and individuals, 'so as to generate strategic social innovations through synergy' (KTO, HKBU 2012). S-L is an excellent platform for the operation of KT: knowledge learned and created in the university is spread to the community through service. Through KT, the OSL aims to forge close ties with faculty, students and the general public to create a progressive Hong Kong society and world. It can be said that KT is core to the LU's motto 'Education for Service'.

Indeed, the mission of whole-person education cannot be achieved without using S-L as a vehicle for KT. This theoretical framework informs the current practice of S-L at LU.

\section{IMPLEMENTATION OF S-L AT LU: FROM COURSE CONCEPTION TO COURSE EVALUATION}

Development of S-L Courses and Their Endorsement Process

Quality assurance is an important element in creating S-L courses, so development and approval of new courses is the first step in the program's quality assurance. In doing this, the OSL plays multiple roles including those of catalyst, solution provider, process helper, resource linker and confidence encourager (Farmer 1990).

Before the start of every academic year, OSL, together with the Community-Faculty Committee, discuss the direction of the courses and projects for the coming year to ensure that the needs of both the course instructors and the community are met. Developing new courses includes incorporating S-L elements into existing departmental courses and developing independent S-L courses from scratch. At LU, this involves four key stages, namely promoting, planning, initiating and obtaining approval for the courses, before they are officially offered.

\section{Promoting}

Enhancing knowledge of S-L is the first step in instilling the S-L culture on campus, in order for faculty members to respond by integrating $S$-L elements in their courses. OSL promotes the aims and objectives, as well as the values and benefits of S-L, to academic staff through the following means: 
a) S-L events for faculty members

One of the roles of OSL is to provide the opportunity for experienced agencies to meet with interested faculty to discuss opportunities for potential partnerships. OSL also invites various experts in S-L to share the design of their programs and stories of success with the faculty at events such as themed luncheons, faculty training and S-L conferences. These are platforms for faculty members and community partners to meet and understand more about the relationship between academia and the community, in particular how win-win partnerships can be fostered.

b) Resource sharing OSL regularly shares useful S-L resources with faculty members and provides support. These include annual reports, newsletters and student assessment tools. Various publications and online resources are also available on the OSL website and in the university library. OSL makes sure that the collection in the library is up to date by regularly making purchase suggestions to the librarians.

c) Meetings with course instructors OSL staff meet with course instructors to talk in greater detail about the S-L concept and to explain how S-L can enhance student learning and faculty's professional development through possible partnerships at LU. They also address concerns course instructors may have and suggest service opportunities that are highly relevant to their course content, students' needs and intended learning outcomes, at the same time addressing a social need.

\section{Planning}

During the promotion stage, some faculty members become interested in the S-L pedagogy and decide to officially incorporate S-L in their courses. They then put forward a proposal, with support from OSL, which addresses the following:

- evidence of community needs and student demand for the proposed course/S-L component

—intended student learning outcomes

- relationship between the proposed service project and course content

- how the S-L project (both processes and final product) will benefit the community

- course components, respective roles of different stakeholders (for example, OSL, community agencies) and resource implications

- how the course relates to (and is different from) existing S-L courses

- student assessment mechanisms.

- For independent S-L courses (Mode 3), OSL considers the availability of academic expertise, as well as the above items. 


\section{$3 \quad$ Initiating}

After careful research and planning, interested course instructors complete a form containing the following items.

a) The course:

- Course title

- Course description

- Course structure and content

—Learning outcomes and measurement

- Assessment criteria and weightings

- Reading list (if any).

b) The service project(s):

- Project title(s)

- Aims and objectives

- Student number

- Service target and number

- Project nature and content

- Roles and responsibilities of OSL coordinators, course instructors, agency supervisors and students

- Schedule

- Budget.

\section{Obtaining approval before launching}

For departmental courses, after the course instructor has consulted OSL, the course proposal is first discussed at the departmental level and then submitted to the S-L Programme Committee. The course is endorsed by the Department Board and Curriculum Committee of the relevant department, which is responsible for submitting the course syllabus to the Academic Quality Assurance Committee (AQAC) and finally to the Senate for consideration for endorsement and approval. Independent courses designed and taught by OSL go through similar procedures.

\section{Operation and Quality Assurance of S-L Courses}

Under both the existing practice and the proposed future development (that is, the Service-Learning Requirement (SLR) for graduation in the 2014-15 academic year), partially integrated courses (departmental courses with S-L elements) serve the most number of students. OSL works closely with course instructors and community agencies as it conducts a specific, standardised implementation process to ensure that each course meets the standards of teaching and learning, as well as community needs. The implementation process involves four major stages: preparation, training, project, and assessment. The following sections outline the existing practice, and new arrangements in view of the development of SLR are also specified. The whole process is coordinated by experienced OSL staff who have at least two years working experience in OSL or the education/training field, monitored by senior OSL staff with more than four years S-L experience. 


\section{Preparation}

a) Roles of OSL

During this stage, ideally three months prior to the term's commencement, course coordinators from OSL confirm with course instructors on courses that will be offered with S-L elements. At the same time, they also identify and liaise with service agencies that are able to provide student placement opportunities and supervision. Apart from sharing the rationale and objectives of S-L, they discuss with the agency supervisors the project arrangements, such as duties and responsibilities, and come to an agreement before the commencement of the courses.

b) Roles of course instructors Course instructors also modify the course structure by integrating S-L (the 30 service hours) into their courses. Currently, in some courses, the service-learning element replaces the traditional tutorials, whereas in other courses students can choose to participate either in the servicelearning project or tutorials. In the future, under the SLR, students will still be given this freedom, but whether they opt to participate in the S-L project and therefore fulfil the SLR has to be clearly stated during course registration.

c) The first lecture A student guideline with all relevant materials is prepared by OSL coordinators prior to the first lecture of each course and a briefing session is arranged and delivered by course instructors and OSL coordinators during the lecture. Students also fill out pre-test questionnaires that assess their performance on the intended S-L outcomes (the Seven Domains mentioned above), namely subject-related knowledge, communication skills, organisation skills, problem-solving skills, research skills, civic orientation and social competence.

\section{Training}

a) Agency orientation

Before actual involvement in service projects, students need to be familiar with the background of the agencies. OSL course coordinators arrange agency orientations for students where they meet their agency supervisors and get to know about the agency and its plans. This event engages students by arousing their interest and their passion to serve and learn in the particular service context.

b) Training workshops

Training workshops are held by course instructors and/or OSL coordinators and sometimes by other professional trainers (such as social workers experienced in working with the elderly) as well, to equip students with the necessary skills. These workshops focus on specific elements that help students with the designated tasks of their projects. Students also receive training in general skills that are relevant to $S-\mathrm{L}$, such as basic theories of experiential learning and reflective cycles, 
teamwork, critical thinking and research skills. There is an aptitude test for students to complete, so that both students themselves and OSL get to know the students' characters, strengths and weaknesses. Following are some examples of questions raised at the training workshops:

-What is S-L?

-Why do you participate in S-L?

-What are the roles and responsibilities of students?

- How is the project related to course materials?

-What are the expected learning outcomes (both subject-related and for personal development)?

-What social issue(s) could potentially be addressed?

-What are the expected outcomes for or impacts on different stakeholders?

-What are the students' expectations of participating in S-L and how likely will these expectations be fulfilled via S-L?

Each project is of a unique nature and is set in a different social context. OSL therefore strives to work closely with departments in providing more specific information and skills training for the students. Course instructors can take this opportunity to further elaborate the rationale and underlying principles of the project, in relation to the course objectives, so as to help students recognise the links between them. In addition, agencies may offer workshops that provide very specific information for and/or train students who work with a special community. Examples are skills for interviewing elderly people with depression, skills for communicating with patients on rehabilitation, and training in the culture and customs of South Asians.

\section{Project}

Agency supervisors provide professional guidance to students in planning, implementing and evaluating their proposed tasks in the project. Within the course lectures, course instructors introduce case studies and topics related to the specific S-L projects to deepen students' understanding of the subject-related knowledge as well as to optimise the integration of S-L elements into the course.

a) Consultation meetings In experiential learning, reflection is particularly important because it makes the learning process continuous. Reflection clarifies the values behind the students' academic and community experiences and raises students' awareness of their social responsibility. There are thus at least two consultation meetings in each course for each project group, which allow students to track their learning progress and consider ways to improve their service quality, as well as further strengthen links with the course materials. Course instructors, coordinators from OSL and sometimes the agency supervisors are involved in these meetings. 
Before the consultation meetings, course instructors design a set of reflective questions related to both the service project and the subject matter to facilitate students' reflection. At the same time, students are asked to provide an update of both their progress and their team's performance so that they can evaluate their personal and team development. Apart from this, OSL has prepared a Reflective Diary and a Consultation Guideline for general use, which is given to students to facilitate their reflection and learning consolidation. Questions such as the following will be asked at the meetings:

-What is the most impressive moment so far? How did it affect you?

-What have you observed in the project that links with the course materials?

-What is the relationship between the service and the social issues?

- Have you achieved your learning goals and objectives? How?

Course instructors and coordinators from OSL also familiarise themselves with the service projects and related activities, which allows them to provide timely feedback to the students. It is also a good time to collect students' comments on the course/project arrangements and their suggestions for improvement. Through this consultation and observation, program quality is monitored and students are kept on the right track through regular support.

b) Reflective meetings Since reflection is of utmost importance in the S-L learning process, OSL organises a reflective meeting (more than one session is offered) to gather together all students involved in S-L in the term to review their learning progress halfway through the project. Students share their project nature and content, observations and inspirations, links between their experiences and academic knowledge, as well as personal development. They are guided to further understand the reflective cycle by applying their own service and learning experiences to it. The meeting serves as a platform for students from different courses to share their learning and experiences with each other, opening another channel to their understanding of social needs. OSL also listens to feedback from students for program improvement.

c) Internal meetings among OSL coordinators Throughout the term, coordinators from OSL communicate regularly with both the course instructors and the agencies to keep track of project progress and students' performance. In the middle of the term, there is a meeting for all the coordinators to share the project's progress and the students' performance - the difficulties they have encountered, as well as good practices for program development. Coordinators also 
share feedback collected from students, agencies and course instructors so that they can address any issues or modify materials for use in the second half of the term.

\section{Evaluation and assessment}

a) Evaluation by students

Upon completion of the project, all students complete post-test questionnaires, which are sent to their OSL coordinators. There is also a peer review where students assess the performance of their group members. In addition, students are required to submit a group project report and individual reflective essays, focusing on academic knowledge enhancement, learning outcomes, and their reflection. These reports and essays are graded by the course instructors. OSL also conducts content analyses of the reflective essays to investigate the process of the students' learning.

b) In-class presentations and report-back celebrations All participating students engage in in-class presentations. OSL also hosts report-back celebrations for outstanding groups. These provide a platform for all OSL coordinators, social service agency supervisors, course instructors and students to share the fruits of the teaching and learning and the impact of the services on the community. It is also an opportunity for students to practise their presentation skills and share their learning outcomes and reflections with others. Students' presentations are assessed based on the course requirements set out by the course instructors, and their performance is counted towards their final grades. Sometimes agency representatives are also invited as members of the judging panels, helping to assess students' presentation skills and content. In some courses, the scores given by the agencies become part of the final grades.

c) Focus groups Focus groups are conducted by OSL staff to gain a deeper understanding of the students' learning experience and continually improve the operation of the courses and projects.

d) Evaluation by course instructors and agency supervisors Course instructors assess the service products (for example, videos, strategic plans), which are strongly related to the course content. OSL coordinators also hold evaluation meetings with both the course instructors and the agency supervisors. In view of the SLR, OSL is currently piloting a summative questionnaire which is to be filled out by course instructors and agency supervisors at the end of the service project. Using the summative questionnaire, course instructors and agency supervisors assess students' performances in the S-L project based on a standardised Service-Learning Outcome Indicators Rubric Table, which has been formulated according to the Seven Domains. In other words, different stakeholders will be assessing the students using the same criteria and in terms of measurable learning outcomes. This is believed 
Table 3: Implementation process of the Partially Integrated Course Mode (i.e. departmental courses) to increase the rigour of the course and project evaluations, and to ease comparisons between the perceptions of different stakeholders. OSL also encourages course instructors to adopt them in their official assessments.

Table 3 below summarises the course implementation procedure and related assessment and quality assurance mechanisms discussed above. It should be noted that the agency visits, training and workshops, consultation meetings, reflective meetings, and in-class presentations and/or report-back celebrations are all mandatory in S-L at LU.

\section{Responsible Stages parties}

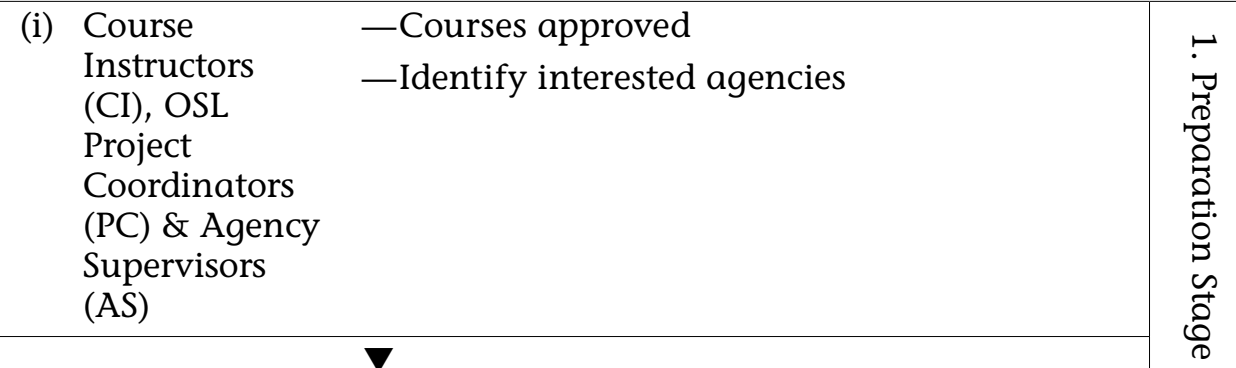

(ii) CI \& PC -Integrate S-L into courses, prepare necessary S-L guidelines for students

-Modify pre- and post-test questionnaires by adding specific subject-related knowledge items

(iii) CI, PC \& $\quad-1$ st lecture: briefing and recruitment of Students (S) students

-1st week: students make tentative choices for their service sites within this week

-2 nd week of term: finalise student lists and project groups

(iv) CI \& PC - Pre-test questionnaires to be filled out by all students

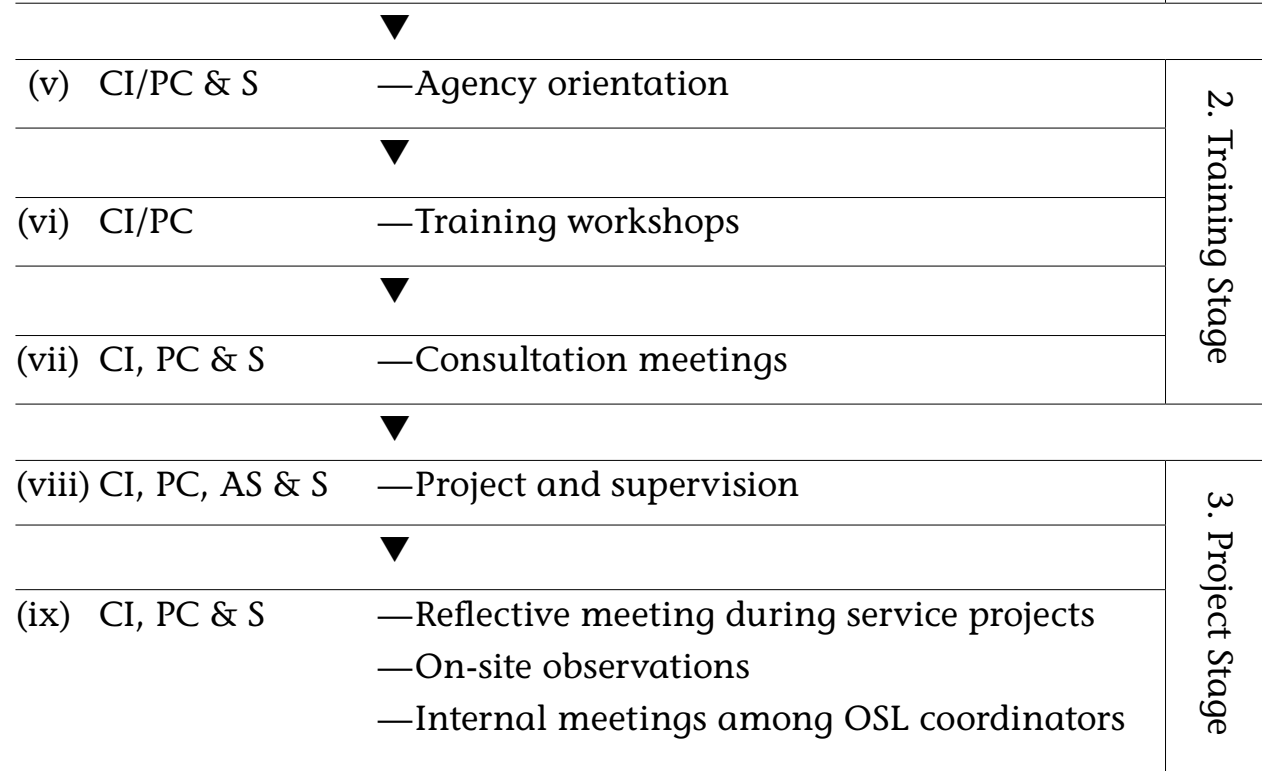




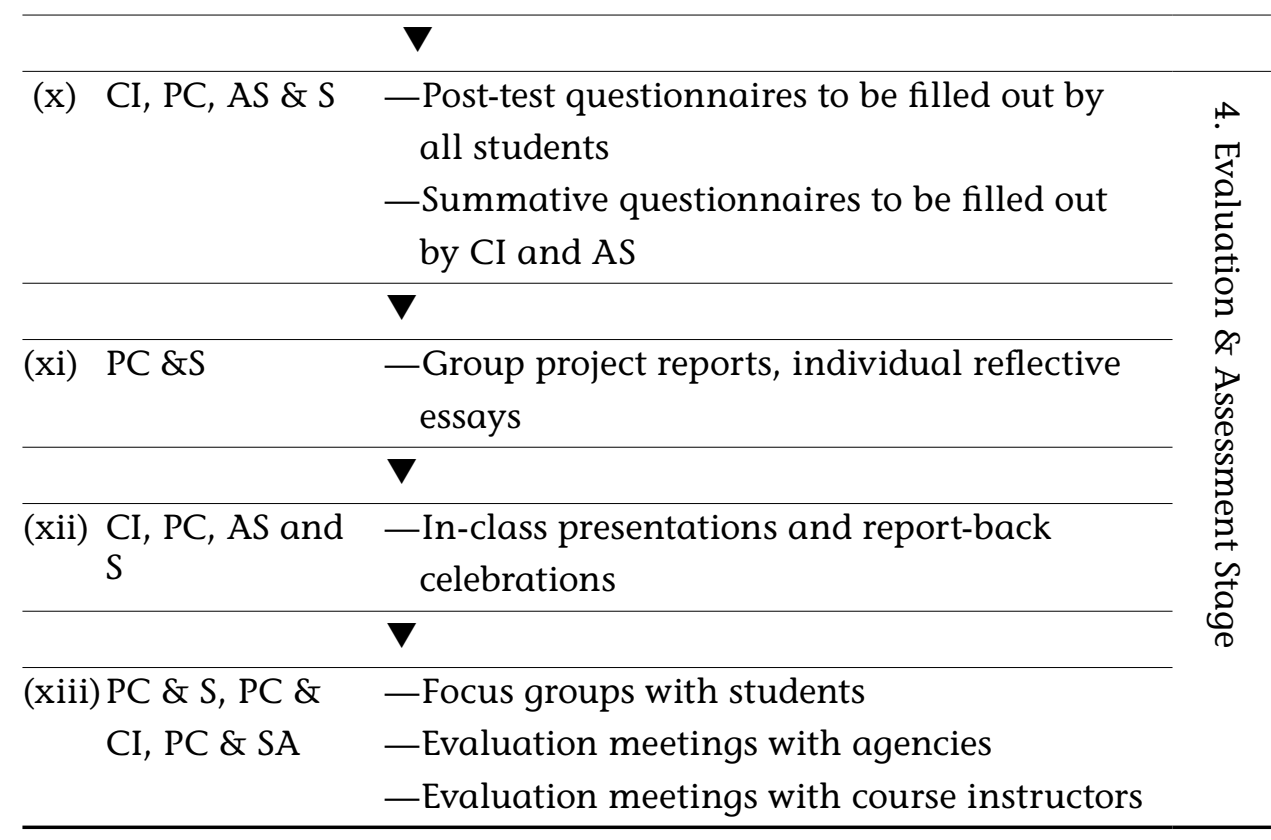

LESSON LEARNT IN INSTITUTIONALISING S-L AT LU: THE IMPORTANCE OF FACULTY TRAINING AND SUPPORT

As with other universities with a similar set-up, such as the Office of Service-Learning at The Hong Kong Polytechnic University (Hong Kong) and the Service-Learning Centre at the Fu Jen Catholic University in Taiwan, a primary task of the OSL is to facilitate course development (Bringle \& Hatcher 1996). Apart from adopting the course conception process as outlined above, OSL at Lingnan University has also come to realise the importance of utilising different creative means to start dialogue with faculty regarding S-L and to support them in both course development and S-L-related research through providing advice and liaison between faculty members and other community partners (that is, social service agencies). To this end, faculty training and support, including a faculty retreat, faculty workshops and a faculty resources website will all be put in place in the coming academic year. The retreat will allow faculty to work out concrete action plans in preparation for SLR. The workshops will address topics that are of most interest and relevance to faculty, such as student assessment and research. The website will include both local and international information and resources on S-L and the community, which will be updated regularly.

Experience also tells us that faculty would appreciate some external incentives, such as having a coordinator in their department who oversees all S-L-related matters or a teaching assistant who communicates between faculty members and the community. The coordinators could actually become S-L associates who not only take care of the administrative arrangements but also act as advocates of S-L within their departments, while the teaching assistants could help to enhance communication among different stakeholders.

Sharing the S-L institutionalisation experiences at LU is very important and the above initiatives could assist this process. It is particularly important that the senior management group of the 
university is made aware of these needs, so they can position S-L as an important initiative and make wise decisions on how best to use the resources and space available at the university.

\section{FUTURE DIRECTION OF S-L IN HIGHER EDUCATION IN HONG KONG}

Although S-L is relatively new among higher education institutions in Hong Kong, quite a few universities (for example, University of Hong Kong, Polytechnic University of Hong Kong) are trying to use $\mathrm{S}$-L as a teaching tool in their classes. Through the collaborative efforts of the Higher Education Service-Learning Network, it is hoped that more joint research and programs will be explored in order to create an S-L academic evidence base.

\section{Measurement and Validation of Impacts of S-L on Students and Graduates}

Undoubtedly, S-L is an educational activity that requires rigorous assessment and evaluation. Gathering evidence from empirical studies of the learning outcomes of S-L programs is therefore of paramount importance. To date, much of the data for these studies has come from students' perceived learning outcomes in completed pre- and post-course questionnaires, which has also been the practice at LU, as described above. Apart from this, LU has begun conducting studies which compare students who have participated in S-L with those who have not; that is, longitudinal studies on S-L impacts on students. Few studies, however, focus on the cumulative effect - otherwise known as the 'dose effect' - S-L has on students who have had multiple S-L experiences, or the effects an S-L course or project has on students at different points of time over an extended period, as highlighted by Eyler (2000). The OSL at LU is now starting to conduct studies that fill these two gaps, the results of which will be shared within the S-L network.

Some studies have shown that students engaged in S-L are more likely to participate in community service and to have a heightened sense of civic responsibility after graduation (for example, Astin et al. 2000; Misa, Anderson \& Yamamura 2005; National Commission on Service-Learning 2002). This type of research on graduates is currently lacking in Hong Kong and should be made one of the priorities in institutional S-L research. The effect of different factors, such as the nature of the S-L project (for example, direct versus indirect services), area of studies and number of years since graduation, could also be explored.

\section{Development of a Progressive S-L Model}

As S-L gradually becomes mainstream in Hong Kong, higher education and LU staff, as educators, need to ask how students can develop academically, as well as in terms of civic efficacy, by progressing through stages in a well-designed S-L model, echoing the above need to study the cumulative effects of multiple S-L experiences on students. 
At LU, staff are exploring the possibility of adopting a progressive model, in which students go through different stages of S-L with different learning focuses. First, they are encouraged to start their S-L journey by taking an introductory S-L course (in the case of LU, a Mode 3 course offered by OSL). In their second and third year, students can then continue to deepen their S-L experience by taking S-L courses in their own areas of study. Meanwhile, they can take part in cross-border S-L programs during term and summer breaks, learning and serving in an overseas location. Finally, as students approach graduation, they can integrate S-L elements into their final year projects or practicums as S-L would be an excellent platform from which to translate their cumulative disciplinary knowledge and competencies into projects that address community needs. Each step in this progressive model would link closely and each would prepare students for the next step, while reinforcing what they have learned in the previous course. This progressive model could be further explored as a pilot at $\mathrm{LU}$, reflecting our whole-education philosophy.

\section{CONCLUSION}

Campus engagement in the community can take many forms, from community work to internship to community-based research. It is, however, the belief of LU that S-L is the most meaningful way for cultivating a giving culture. First and foremost, it encompasses the central mission of higher education - teaching and learning - and involves both faculty and students in educationally meaningful service activities that address real community issues (Bringle \& Hatcher 2002). Unlike much other pedagogy, students, faculty and community members are all involved as co-learners, co-educators and co-generators of knowledge (Felten \& Clayton 2011). The resulting enhanced skills and competences can be applied then to almost all other university and life experiences of students. S-L also involves a relatively long engagement process that requires ongoing dialogue between the university, community partners and service targets (Zlotkowski 1999), rather than a one-off experience that lacks commitment and sustainability. The heightened civic involvement has also proven to have a farreaching impact on students, even beyond graduation, as shown in studies done with graduates with S-L experience (Astin et al. 2000; Astin et al. 2006).

Being the first university in Hong Kong to make S-L an academic subject, we can share the academic content and our experiences with other institutions. Undoubtedly, successful institutionalisation of S-L in higher education institutes requires the support and contribution of various stakeholders, the most important being senior management of educational institutions. They need to commit resources to develop effective citizenship among students, to address the needs of communities through the application of knowledge, and to form creative partnerships between the university and the community (Bringle \& Hatcher 
1996). The work of developing and implementing S-L courses and monitoring their quality can be daunting, so having a designated S-L team, such as the OSL, is highly desirable. Having $\mathrm{S}$-L coordinators and associates in each participating academic department would also contribute to easing the burden, which is a goal that OSL at LU is currently pursuing.

\section{ACKNOWLEDGEMENTS}

The authors wish to acknowledge that Dr Elaine Tang Hau Hing has assisted in the final editing of the manuscript.

\section{REFERENCES}

Astin, A, Vogelgesang, L, Ikeda, E \& Yee, J 2000, How service-learning affects students, Higher Education Research Institute, UCLA, Los Angeles, CA.

Astin, A, Vogelgesang, L, Misa, K, Anderson, J, Denson, N, Jayakumar, U, Saenz, V \& Yamamura, E 2006, Understanding the effects of service-learning: A study of students and faculty, Higher Education Research Institute, UCLA, Los Angeles, CA.

Bringle, R \& Hatcher, J 1995, 'A Service-Learning Curriculum for Faculty', Michigan Journal of Community Service Learning, vol. 2, pp. 112-22.

Bringle, R \& Hatcher J 1996, 'Implementing service learning in higher education', The Journal of Higher Education, vol. 67, no. 2, pp. 221-39.

Bringle, R \& Hatcher J 2002, 'Campus-community partnerships: The terms of engagement', Journal of Social Issues, vol. 58, no. 3, pp. 503-16.

Chan, A CM \& Ma, C CM 2006, The Service-Learning and Research Scheme: The Lingnan model, Office of Service-Learning, Lingnan University, Hong Kong.

Chan, A CM, Lee, KM \& Ma, C CM 2009, 'Service-Learning model at Lingnan University: Development strategies and outcome assessment', New Horizons in Education, vol. 3, pp. 57-73.

Dewey, J 1938, Experience and education, Collier Books, New York.

Eyler, J 2000, 'What do we most need to know about the impact of servicelearning on student learning?', Michigan Journal of Community Service Learning, Special Issue, Fall, pp. 11-17.

Farmer, D 1990, 'Strategies for change', in D Steeples (ed.), Managing change in higher education, Jossey-Bass, San Francisco, CA, pp. 7-17.

Felten, P \& Clayton, P 2011, 'Service-learning', New Directions for Teaching and Learning, issue 128, pp. 75-84.

Furco, A 1996, 'Service-learning: A balanced approach to experiential education', in B Taylor (ed.), Expanding boundaries: Serving and learning, Corporation for National Service, Washington, DC, pp. 2-6.

Knowledge Transfer Office, Hong Kong Baptist University (KTO, HKBU) 2012, 'What is knowledge transfer?', viewed 28 March 2013, http://kto. hkbu.edu.hk/eng/channel.php?channel=what-is-knowledge-transfer.

Kolb, D \& Fry, R 1975, 'Toward an applied theory of experiential learning', in C Cooper (ed.), Theories of group process, John Wiley, London.

Misa, K, Anderson, J \& Yamamura, E 2005, 'The lasting impact of college on young adults' civic and political engagement', paper presented at 
the Association for the Study of Higher Education Annual Conference, Philadelphia, PA, 19 November.

National Commission on Service-Learning 2002, Learning in deed: The power of service-learning for American schools, Columbus, $\mathrm{OH}$.

Stanton, T, Giles D \& Cruz N 1999, Service-learning: A movement's pioneers reflect on its origins, practice, and future, Jossey-Bass, San Francisco, CA.

University Grants Committee (UGC) 2012, 'Knowledge transfer', viewed 5 April 2013, www.ugc.hk/eng/ugc/activity/kt/kt.htm.

Xin Jun \& Ma C (eds) 2010, Service-learning in Asia: Curricular models and practices, Hong Kong University Press, Hong Kong.

Zlotkowski, E 1999, 'Pedagogy and engagement', in R Bringle, R Games \& E Malloy (eds), Colleges and universities as citizens, Allyn \& Bacon, Boston, MA, pp. 96-120. 